\title{
Too many memories
}

\author{
Sit down and tell me your story. I'm listening.
}

\section{Pamela Sargent}

wasn't the first to practise my profession, but I was one of the pioneers, before we understood the scope of the problem we faced. My first client was Mamie Lagerfelt, and her memory files were in such disorder that she had even forgotten how many other names she had used. What she did remember very clearly (and I was struck by the irony of this later) was a news headline she had seen a century earlier — "No More Senior Moments", on a story about the first successful gene therapy for Alzheimer's disease. Mamie's great fear had always been that she would fall victim to Alzheimer's, as had several of her relatives.

"We used to call it a Senior Moment," she explained, "when you did something like forget the name of one of your children, just drew a complete blank." She no longer had to worry about Alzheimer's and having her last years filled with 'senior moments'. Her memory and her sense of herself would remain intact. You're smiling, but as I said, we didn't yet know what we were facing. We were still calling ourselves 'memory coaches' or 'personal organizers', as our clients were put off by the term 'therapist'. And back then, most of us thought that the problem was one of untidy minds that only needed straightening up.

Mamie had always been messy, and also something of a pack rat. Consequently, after having gone through her first memoryclearance procedure, she couldn't bear to get rid of anything permanently: she had downloaded and saved old memories in her personal artificial intelligence; in her town's AI; in the Novum City memory banks; in her daughter's new neural-storage system; and elsewhere, so that even her AI link couldn't locate specific memories without an extensive search - at the end of which she often forgot what memories she had been looking for in the first place. Some tidying up, proper organization of her memories in easily accessible files - I thought that would solve the problem.

It took months to help Mamie organize her memories. But it was becoming evident that her mental untidiness and exasperating incoherence were symptomatic of a deeper disorder than mere sloppiness. Colleagues reported similar problems with the clients they were coaching. "There's no framework there," Dorothea Singh said to me, "nothing to hang the memories on."

That's right - Dorothea Singh, the founder of Narrative Therapy and Reconstruction. By now you'll have guessed that Mamie was the 'Client X' of Dorothea's most famous case history.

You already know what Dorothea's most important insight was - that the reason our client had so much trouble with her memories was that she possessed no narrative structure on which to locate them. Mamie's memories had become isolated events, fragments without context. She couldn't really remember them, even after she accessed them, because they weren't part of a story.

For Mamie, recalling too many memories was as confusing for her as not having any at all.

In retrospect, Dorothea's insight into this dysfunction seems obvious. Mamie - and other 'first-generation' longlifers - lacked a sense of continuity. They were easily distracted, incapable of extended concentration; people who had experienced life as a series of discrete moments with no unifying framework. The central principle of narrative therapy, according to Dorothea, was that memory and coherent recollection lay in the ability to tell a story, to make an epic of all of one's memories.

Mamie, as had so many others, had drifted passively from one distraction to another, and that had severely damaged her ability to weave the fabric of her memories and life into a continuous narrative. Because she couldn't tell a good story, she couldn't really remember anything, even when the incidents of her life were easily available for recollection.

Being a memory coach wasn't enough; we had to become narrative therapists, and the demand for our services could only grow. There were many like Mamie, people who had been unable to resist the distractions of their time, who had become little more than spectators of events and passive participants in simulated experiences. But we had hopes...

Yes, our failures were legion. It's almost impossible to have a successful outcome unless the client is willing to erase his past memories and start afresh. That's simply too close to death for most people: however fragmented a self might be, it rarely wants to lose that self. But in the lives of the few who had avoided Mamie's problem, we saw a remedy - better yet, a way to prevent narrative dysfunction.

These few were the fortunate ones who had exercised their minds, who had read many books in various formats and studied difficult subjects in depth, who had built up the neural connections in their brains that gave them the continuity they needed to tell good stories. Long novels with lots of characters and narrative strands; lengthy historical accounts that enable one to understand one's historical context - that's the way to build yourself up. Work out with some Tolstoy and Balzac! Even better, keep a journal, master the art of telling a good story. All that's necessary, as the old saying goes, is to sit down and open a vein.

Excuse me - I got carried away. Historically, such pursuits were always the province of the few, and now we have even more distractions than people did in the old days. I realize that we narrative therapists are probably fighting a losing battle, but stories must be told! Our health demands this special way of ordering our minds.

Well, I hope you have a good story to tell me. I haven't heard a good one lately.

Nebula-award-winning Pamela Sargent's many books include the The Shore of Women (1986), Ruler of the Sky (1993) and Climb the Wind: A Novel of Another America (1999). Child of Venus will be published by Avon/Eos in 2001.

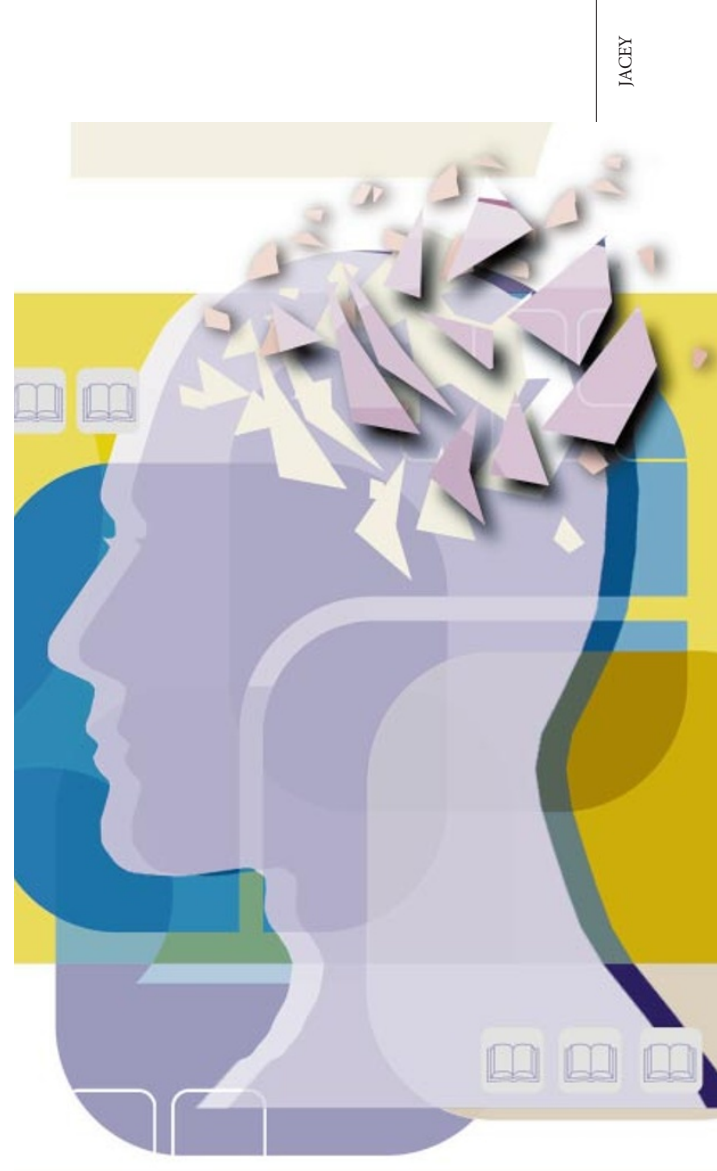

